\title{
The filtering capacity of selected Eastern Cape estuaries, South Africa
}

\author{
UM Scharler ${ }^{1}$ and D Baird ${ }^{*}$ \\ ${ }^{1}$ Chesapeake Biological Laboratory, University of Maryland, Center for Environmental Studies, Solomons, MD 20688, USA \\ Smithsonian Environmental Research Center, 647 Contees Wharf Road, Edgewater, MD 21037, USA \\ ${ }^{2}$ Department of Zoology, Nelson Mandela Metropolitan University, PO Box 77000, Port Elizabeth 6031, South Africa
}

\begin{abstract}
Four Eastern Cape estuaries, the Kromme, Gamtoos, Swartkops and Sundays Estuaries have a permanent connection to the adjacent ocean, but differ in the amount of freshwater inflows as well as in the land-use patterns in their respective catchment areas. The nutrient loading to the four estuaries in terms of phosphate, nitrate, nitrite and ammonia therefore varies. The aim of the study was to show how the nutrient loads received by the estuaries differ, and how they act as filters for nutrients. Discriminant analysis revealed such contrasts: The lower reaches of the four estuaries are similar in their inorganic nutrient concentrations, but concentrations diverge in their upper reaches and in the inflowing river water.
\end{abstract}

Keywords: filtering capacity of estuaries, nutrient loading, phosphate, nitrate, nitrite, ammonia, South Africa

\section{Introduction}

Estuaries are recognised as productive ecosystems, which are of economic, recreational and aesthetic value. Increasingly, the estuarine ecosystem is threatened through anthropogenic influences such as pollution, excessive freshwater abstraction in the catchment and over-fertilisation from nutrients in agricultural and urban runoff. Estuaries, as the end-users of water of the entire catchment, reflect the land-use of the catchment and are important areas to trap nutrients and other chemical compounds before discharge occurs into the adjacent coastal ocean. As popular areas for settlements and recreation, estuaries have been impacted around the world. In South Africa several cities, agriculture, tourism, residential developments, and recreational activities are concentrated along the coast (Morant and Quinn, 1999), but largely focus around or adjacent to estuaries. These impact estuaries in the way of nutrient over-enrichment, siltation, and reduced freshwater inflow due to freshwater abstraction. In this study we investigated the differences between four Eastern Cape estuaries (Kromme, Gamtoos, Swartkops, Sundays) in terms of their inorganic dissolved nutrient status and how well the estuaries act as filters as transition zones between the river and the sea. The hypotheses tested in this study highlight that all four estuaries differ in terms of their inorganic dissolved nutrient status in the riverine reaches just above the tidal head, but that concentrations in their lower reaches are very similar. In this case, the estuaries would act as important filters for nutrients derived from their catchment areas.

The four Eastern Cape estuaries under investigation are situated along the south coast of South Africa (Fig. 1) and belong to the $23 \%$ of South African estuaries that have a permanent connection to the sea (Whitfield, 2000). The four estuaries differ in the amount of inorganic dissolved nutrients (phosphate, nitrate, nitrite, ammonia) they receive from runoff, due to different land

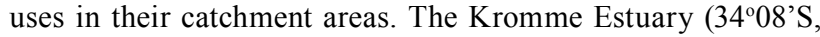

* To whom all correspondence should be addressed.

용 +2741 5042-341/041/690; fax: +2741 5042-317;

e-mail: dan.baird@nmmu.ac.za

Received 12 January 2004; accepted in revised form 23 May 2005.

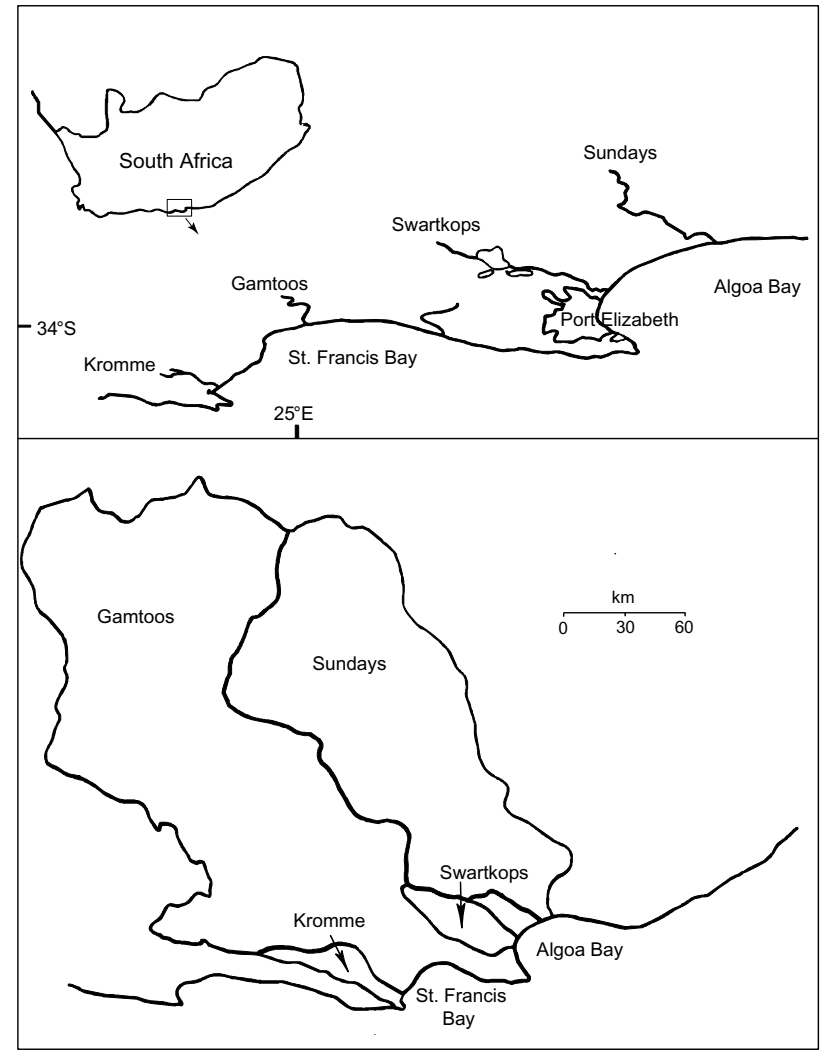

Figure 1

The location of the Kromme, Gamtoos, Swartkops and Sundays Estuaries along the South African coast, including an indication of their catchment size.

$\left.24^{\circ} 51^{\prime} \mathrm{E}\right)$ is subject to major freshwater abstraction for greater than 20 years by two dams that have a storage capacity of ca. $133 \%$ of the mean annual runoff (MAR) of about $105.5 \times 10^{6} \mathrm{~m}^{3}$ (Reddering and Esterhuysen, 1983). The Mpofu Dam, completed in 1982, is only $4 \mathrm{~km}$ from the tidal head of the Kromme Estuary which only receives freshwater after rains when overtopping of both dams occurs. Nutrient additions to the estuary occur when 
freshwater reaches the estuary (Scharler and Baird, 2000). Agriculture is practised on a limited scale along the lower reaches of the estuary and on the hills further upstream and natural vegetation occurs along the middle and upper reaches as well as along its biggest tributary, the Geelhoutboom, entering ca. $7 \mathrm{~km}$ from the mouth. Other numerous but small tributaries along the entire length of the Kromme Estuary only flow in a response to rain and are dry at other times.

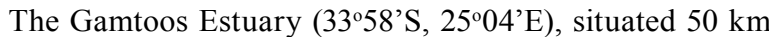
west of Port Elizabeth, is ca. $20 \mathrm{~km}$ in length and its only tributary, the Loerie River, enters at about $8.5 \mathrm{~km}$ from the mouth. The catchment area is about $34500 \mathrm{~km}^{2}$ and extends far into the interior (Snow et al., 2003). The MAR of the catchment is approximately $485 \times 10^{6} \mathrm{~m}^{3}$ and the total reservoir capacity of the catchment is estimated at $255 \times 10^{6} \mathrm{~m}^{3}$ (Noble and Hemens, 1978; Midgley et al., 1994). There are three major impoundments in the Gamtoos River catchment. The Beervlei Dam on the Groot River has a storage capacity of about $150 \%$ of the MAR, the Kouga Dam on the Kouga River retains about $85 \%$ of the MAR and the Loerie Dam retains approximately $20 \%$ of its MAR of $21 \times 10^{6} \mathrm{~m}^{3}$ (Heydorn and Grindley, 1981). Stock farming and the cultivation of vegetable crops and fodder farming occur in the catchment area. The Gamtoos River floodplain surrounding the Loerie and Gamtoos Estuaries, is extensively used for crop cultivation under irrigation (Heydorn and Grindley, 1981) An agricultural drainage pipe, ca.16.5 km from the mouth and draining an agricultural area of about 50ha, discharges approximately $250 \mathrm{~m}^{3} \cdot \mathrm{d}^{-1}$ of water into the Gamtoos Estuary. A non-point source of nutrients into the Gamtoos Estuary is the leaching of groundwater, containing dissolved fertilizer, from the adjacent agricultural fields at a mean rate of about $276 \mathrm{~m}^{3} \cdot \mathrm{d}^{-1}$ (Schumann and Pearce, 1997). Natural fringing vegetation is absent along most of the Gamtoos Estuary.

The Swartkops Estuary (32 $52^{\prime}$ 'S, $\left.25^{\circ} 38^{\prime} \mathrm{E}\right)$ lies within the municipal boundary of Port Elizabeth, with a relatively pristine upper catchment about $1360 \mathrm{~km}^{2}$ in size and a mean annual runoff of $84.2 \times 10^{6} \mathrm{~m}^{3}$ (Reddering and Esterhuysen, 1981a). The lower catchment and the area around the estuary are densely populated and numerous industrial activities such as clay mining, salt works, sewage treatment works, wool washeries and tanneries are situated in the region. Point sources of nutrients include the Swartkops River and the Motherwell and Markman Canals which drain an under-serviced, heavily populated residential townships and industrial developments respectively (MacKay, 1993). The Chatty River enters the Swartkops Estuary in the lower reaches and flows through an informal settlement. Freshwater abstraction in the catchment area is restricted.

The Sundays River valley is extensively used for agriculture, mainly citrus cultivation. The Sundays Estuary (334' $\mathrm{S}$, $25^{\circ} 25^{\prime} \mathrm{E}$ ) is about $24 \mathrm{~km}$ in length (MacKay and Schumann, 1990) and its catchment area $\left(20729 \mathrm{~km}^{2}\right)$ lies in a semi-arid region. The mean annual runoff is about $186 \times 10^{6} \mathrm{~m}^{3}$ (Reddering and Esterhuysen, 1981b). The major freshwater abstraction occurs in the upper half of the Sundays River and an interbasin transfer scheme adds water to the Sundays River system, which has increased the average freshwater inflow to the estuary (Archibald, 1983). There are no tributaries to the Sundays Estuary.

The total water exchange times were calculated for each of the four systems using the land ocean interactions in the coastal zone (or LOICZ) water budget modelling protocol. Water exchange times were derived from the ratio $V_{1} /\left(V_{R}+V_{x}\right)$ where
$\mathrm{V}_{1}=$ the volume of the system, $\mathrm{V}_{\mathrm{R}}=$ the daily residual water flux, and $V_{X}=$ daily water exchange flux (Gordon et al., 1996). Total water exchange times are given by Baird (2001) as $87 \mathrm{~d}$ for the Kromme Estuary, 26d for the Gamtoos Estuary, 34d for the Swartkops Estuary, and 42d for the Sundays Estuary. The long exchange time for the Kromme Estuary is probably due to the low rate of freshwater inflow.

Mean annual freshwater inflow rates reported for the four estuaries are: Kromme Estuary (June 1993 - March 1995): $0.07 \mathrm{~m}^{3} \cdot \mathrm{s}^{-1}(\mathrm{SD}=0.14, \mathrm{n}=42)($ Scharler and Baird, 2003a); Gamtoos: 0.4 to $1.6 \mathrm{~m}^{3} \cdot \mathrm{s}^{-1}$ under base flow conditions (Scharler et al., 2003), with an estimated average inflow into the estuary of less than $1 \mathrm{~m}^{3} \cdot \mathrm{s}^{-1}$ (Snow et al., 2003; Schumann and Pearce, 1997); Swartkops Estuary (June 1993 to June 1994): $0.82 \mathrm{~m}^{3} \cdot \mathrm{s}^{-1}$ $(\mathrm{SD}=0.86, \mathrm{n}=26)$ (Scharler and Baird, 2003a); Sundays Estuary (June 1993 to June 1994): $2.74 \mathrm{~m}^{3} \cdot \mathrm{s}^{-1}(\mathrm{SD}=1.03, \mathrm{n}=26)$ (Scharler and Baird, 2003a).

\section{Material and methods}

The Kromme Estuary was sampled between June 1993 and March 1995 on 12 occasions. Water samples were taken at 4 stations in the Kromme Estuary, and one in the Geelhoutboom River tributary near its confluence with the Kromme Estuary. Samples were taken at $0.5 \mathrm{~m}$ intervals from the surface to the bottom. The two stations in the lower estuary were pooled to represent the lower reaches of the Kromme Estuary. The Swartkops and Sundays Estuaries were sampled on 7 occasions from June 1993 to June 1994 at 3 stations (also at $0.5 \mathrm{~m}$ intervals from surface to bottom) in the estuaries to represent the lower, middle and upper reaches. Additional samples were taken at one station in the freshwater reaches of the river. The Gamtoos Estuary was sampled between November 1996 and November 1998 on 6 occasions at 12 stations. The data from the 12 stations in the Gamtoos Estuary were combined to represent the lower, middle, upper and riverine reaches. The data for all 4 estuaries represent the lower, middle, upper and riverine reaches based on geographical considerations. Samples in all four estuaries were taken at all times during spring low tides to reduce the effect of dilution and mixing by seawater as much as possible.

Duplicate water samples were filtered through Schleicher and Schüll (No 6) glass-fibre filters and analysed after Strickland and Parsons (1972) for phosphate, for nitrate and nitrite after Bate and Heelas (1975) as modified from Strickland and Parsons (1972), and for ammonia after Solórzano (1969).

Salinity was measured at the same depth intervals with a CTDS Valeport Ser. 600. Freshwater inflow was measured on each sampling occasion just above the tidal head of the Gamtoos, Swartkops and Sundays Estuaries by measuring the crosssectional area of the river-bed and the flow velocity using an OTT C20 Mini-current meter. Data on freshwater inflow into the Kromme Estuary were chosen to be equal to the amount of water leaving the Mpofu Dam $4 \mathrm{~km}$ upstream of the tidal head. These data were obtained from the Department of Water Affairs and Forestry in Pretoria.

The data were subjected to multiple discriminant analysis (e.g. Hair et al., 1992; software: Statistica Version 5.0) to illustrate differences firstly between the lower, middle, upper and riverine reaches within each estuary and secondly between the 4 estuaries and in terms of the 4 inorganic dissolved nutrients analysed. Discriminant analysis is used to determine which variables discriminate between 2 or more naturally occurring groups (in this case the different estuarine reaches first within 


\begin{tabular}{|c|c|c|c|c|}
\hline \multicolumn{5}{|c|}{$\begin{array}{c}\text { TABLE 1 } \\
\text { Mean values ( } \pm \text { SD; } \mathbf{n} \text { ) of inorganic nutrient measurements } \\
\text { (in } \mu \mathrm{M}) \text { for the Kromme, Swartkops, Sundays and } \\
\text { Gamtoos Estuaries }\end{array}$} \\
\hline & Phosphate & Nitrate & Nitrite & Ammonia \\
\hline $\begin{array}{l}\text { Kromme } \\
\text { Mouth } \\
\text { Lower } \\
\text { Middle } \\
\text { Upper } \\
\text { River }\end{array}$ & $\begin{array}{ll}0.6 & (0.8 ; 70) \\
0.5 & (0.8 ; 94) \\
0.6 & (0.9 ; 117) \\
0.6(0.9 ; 101) \\
0.6(0.5 ; 11)\end{array}$ & $\begin{array}{l}9.2(8.5 ; 70) \\
8.5(8.3 ; 94) \\
8.7(8.2 ; 117) \\
8.9(9.1 ; 101) \\
15.0(4.1 ; 12)\end{array}$ & \begin{tabular}{|l}
$0.8(1.3 ; 66)$ \\
$0.8(1.3 ; 88)$ \\
$0.8(1.4 ; 102)$ \\
$0.7(1.3 ; 85)$ \\
$1.5(1.8 ; 10)$ \\
\end{tabular} & $\begin{array}{l}5.6(4.9 ; 66) \\
4.9(3.1 ; 88) \\
6.1(2.7 ; 109) \\
5.4(6.2 ; 93) \\
9.0(9.3 ; 10)\end{array}$ \\
\hline $\begin{array}{l}\text { Swartkops } \\
\text { Lower } \\
\text { Middle } \\
\text { Upper } \\
\text { River }\end{array}$ & $\begin{array}{l}0.8(0.1 ; 62) \\
2.6(0.9 ; 68) \\
3.9(1.9 ; 64) \\
6.8(3.9 ; 14)\end{array}$ & $\begin{array}{l}12.4(12.5 ; 68) \\
14.2(12.1 ; 68) \\
12.4(13.2 ; 64) \\
23.3(27.9 ; 14)\end{array}$ & $\begin{array}{l}0.8(0.9 ; 62) \\
0.7(0.9 ; 68) \\
0.4(0.4 ; 64) \\
0.7(0.4 ; 140)\end{array}$ & $\begin{array}{l}7.2(2.3 ; 62) \\
7.5(5.9 ; 68) \\
6.8(4.6 ; 64) \\
6.9(5.0 ; 14)\end{array}$ \\
\hline $\begin{array}{l}\text { Sundays } \\
\text { Lower } \\
\text { Middle } \\
\text { Upper } \\
\text { River } \\
\end{array}$ & $\begin{array}{l}0.4(0.4 ; 43) \\
0.5(0.4 ; 58) \\
0.6(0.4 ; 52) \\
0.6(0.4 ; 40)\end{array}$ & $\begin{array}{l}22.3(16.3 ; 44) \\
25.0(21.7 ; 58) \\
33.7(22.9 ; 52) \\
66.7(41.4 ; 40) \\
\end{array}$ & $\begin{array}{l}0.7(0.5 ; 44) \\
0.8(0.6 ; 58) \\
1.0(0.5 ; 52) \\
0.5(0.3 ; 40)\end{array}$ & \\
\hline $\begin{array}{l}\text { Gamtoos } \\
\text { Lower } \\
\text { Middle } \\
\text { Upper } \\
\text { River }\end{array}$ & $\begin{array}{l}0.2(0.2 ; 51) \\
0.4(0.3 ; 63) \\
0.4(0.3 ; 64) \\
0.3(0.3 ; 5)\end{array}$ & $\begin{array}{l}9.3(12.9 ; 51) \\
20.6(28.8 ; 63) \\
60.3(55.7 ; 64) \\
88.6(69.1 ; 5)\end{array}$ & $\begin{array}{l}1.2(1.0 ; 51) \\
1.6(1.2 ; 63) \\
2.9(0.8 ; 64) \\
2.0(0.6 ; 5)\end{array}$ & $\begin{array}{l}6.5(6.3 ; 50) \\
10.5(8.2 ; 63) \\
7.9(5.9 ; 64) \\
5.4(1.3 ; 5)\end{array}$ \\
\hline
\end{tabular}
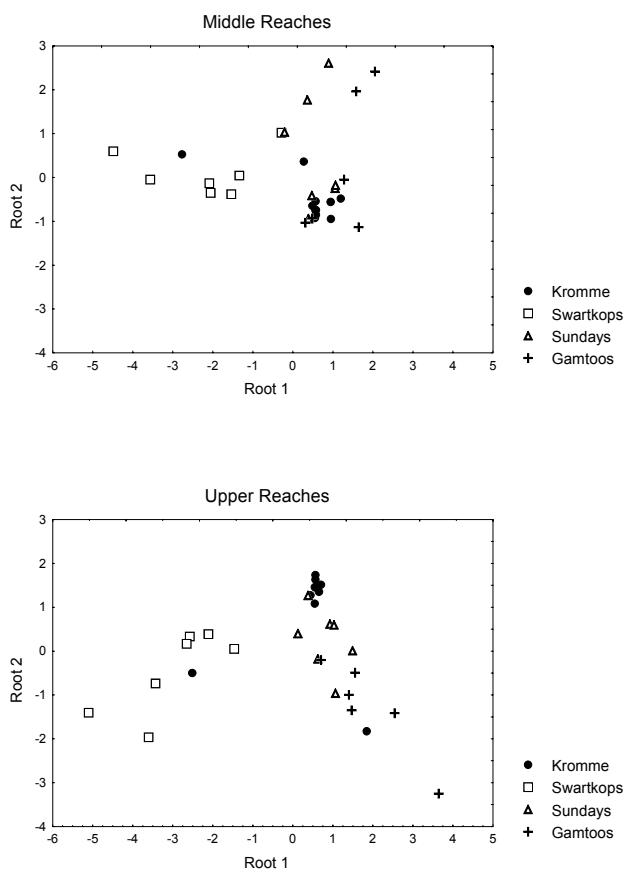

each of the 4 estuaries and then between the 4 estuaries). The difference in groups is calculated with regard to the mean of the variable. Variables in this study are the inorganic dissolved nutrients. The discriminant analysis differs from an ANOVA not in the underlying procedure, but in that different types of statistics are computed. They include e.g. the significance of the contribution of each variable to the discrimination between groups whose contributions to the discrimination do not overlap, a canonical correlation analysis is performed to determine the successive discriminant functions, and individual discriminant scores can be viewed and plotted (e.g. Hair et al., 1992; Software Statistica Version 5.0). When the functions discriminate significantly, it is possible to develop classification matrices (Hair et al., 1992). The classification matrix is a measure of the prediction accuracy of the discriminant function, and its classification scores are calculated with classification functions, determining to which group each case most likely belongs. Predicting to which group a case belongs can be done post hoc, with the same data used to develop the discriminant function, or a priori, using cases which were not part of developing the function. Both methods are acceptable (Hair et al., 1992), and the post hoc prediction was used here. The classification scores are biased towards a better classification score using the post hoc method.

\section{Results}

The salinity distribution along the longitudinal estuarine gradient reflects the restricted freshwater inflow into the Kromme Estuary where mean salinities ranged from $30.6(\mathrm{SD}=6.0)$ near the mouth to $24.4(\mathrm{SD}=10.7)$ in the upper reaches (Scharler and Baird, 2003a). The mean salinity gradient in the Gamtoos Estuary ranged from 30.6 at the mouth to about 0.6 at the head of the estuary (Scharler and Baird, 2003b). In the Swartkops Estuary mean salinities ranged from $33.1(\mathrm{SD}=2.8)$ near the mouth

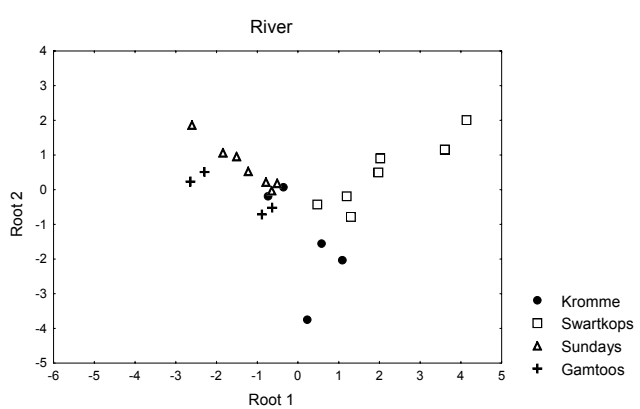

Figure 2

Scatter-plot of the canonical scores derived by multiple discriminant analysis for the middle, upper and riverine reaches ofthe Kromme, Gamtoos, Swartkops and Sundays Estuaries. There was no difference between the lower reaches of the 4 estuaries.

to $14.7(\mathrm{SD}=11.0)$ in the upper reaches, whilst the salinity in the Sundays Estuary from ranged from $26.5(\mathrm{SD}=3.6)$ near the mouth to $9.9(\mathrm{SD}=10.6)$ in the upper reaches (Scharler and Baird, 2003a)

The concentrations of the inorganic nitrogen concentrations were in general highest in the Gamtoos Estuary (Table 1). Highest phosphate concentrations were measured in the Swartkops Estuary, and lowest concentrations in the Gamtoos Estuary. Similar concentration levels of phosphates were measured in the Kromme and Sundays Estuaries. The Gamtoos and Sundays Estuaries, which are both impacted by agricultural runoff showed the highest nitrate concentrations. Lowest concentrations were measured in the Kromme Estuary (Table 1). Nitrite concentrations were overall low probably due to the rapid oxidation of nitrite to nitrate in well mixed and oxygenated waters. A detailed description of salinity and nutrients values is given in Scharler and Baird (2003a; b).

In all 4 systems, higher concentrations of nitrate were measured in the inflowing freshwater compared to the upper estuarine reaches. For phosphate, this was true only in the Swartkops 


\section{TABLE 2}

Results of discriminant analysis of the Swartkops, Sundays and Gamtoos Estuaries (There were no statistically significant differences between the reaches of the Kromme Estuary.) Summary of stepwise analyses: list of variables with discriminant power; Discriminant functions: give results of canonical analyses and significance of the canonical roots that add to the discrimination between groups; Classification matrix: presents to which group (here: lower, middle, upper, riverine reaches) a case (here: concentrations of nutrients included in the analysis) most likely belongs; Discriminant loadings: measure the simple linear correlation between the variables and the discriminant function; Potency Index: A composite measure of the discriminatory power of a predictor variable. Only the variables which discriminate statistically significant between the reaches are listed.

\begin{tabular}{|c|c|c|c|c|c|c|c|c|}
\hline \multicolumn{4}{|c|}{ Summary of stepwise analysis: } & \multicolumn{5}{|c|}{ Classification matrix: \% correctly classified: } \\
\hline & $F$ to enter & p-level & & & Swartkops & \multicolumn{2}{|c|}{ Sundays } & Gamtoos \\
\hline $\begin{array}{l}\text { Swartkops: } \\
\text { Phosphate }\end{array}$ & 9.3 & $<0.001$ & & $\begin{array}{l}\text { Lower Reaches } \\
\text { Middle Reaches }\end{array}$ & $\begin{array}{c}100.0 \\
71.4\end{array}$ & \multicolumn{2}{|l|}{$\begin{array}{l}57.1 \\
14.3\end{array}$} & $\begin{array}{l}50.0 \\
66.7\end{array}$ \\
\hline $\begin{array}{l}\text { Sundays: } \\
\text { Nitrate } \\
\text { Nitrite }\end{array}$ & $\begin{array}{l}4.6 \\
4.5\end{array}$ & $\begin{array}{l}0.01 \\
0.01\end{array}$ & & $\begin{array}{l}\text { Upper Reaches } \\
\text { River } \\
\text { Total }\end{array}$ & $\begin{array}{l}57.1 \\
57.1 \\
71.4\end{array}$ & $\begin{array}{l}57.1 \\
85.7 \\
53.6\end{array}$ & & $\begin{array}{c}66.7 \\
100.0 \\
68.2\end{array}$ \\
\hline Gamtoos: & & & & \multicolumn{5}{|c|}{ Proportional chance criterion: } \\
\hline $\begin{array}{l}\text { Nitrite } \\
\text { Phosphate } \\
\text { Ammonia } \\
\text { Nitrate }\end{array}$ & $\begin{array}{c}50.0 \\
4.6 \\
7.2 \\
9.3\end{array}$ & $\begin{array}{c}<0.001 \\
0.02 \\
0.002 \\
0.001\end{array}$ & & & 25.0 & 25.0 & & 25.1 \\
\hline \multicolumn{4}{|c|}{ Discriminant functions: Statistical Significance: } & \multicolumn{5}{|c|}{ Discriminant loadings: } \\
\hline $\begin{array}{l}\text { Discriminant } \\
\text { function } \\
\text { removed }\end{array}$ & $\begin{array}{c}\text { Canonical } \\
\mathrm{R}\end{array}$ & $\begin{array}{l}\text { Chi- } \\
\text { square }\end{array}$ & p-level & & $1^{\text {st }}$ & $2^{\text {nd }}$ & $3^{\text {rd }}$ & $\begin{array}{l}\text { Potency } \\
\text { Index }\end{array}$ \\
\hline $\begin{array}{l}\text { Sundays: } \\
0 \\
1\end{array}$ & $\begin{array}{l}0.75 \\
0.28\end{array}$ & $\begin{array}{c}21.9 \\
1.9\end{array}$ & $\begin{array}{c}0.001 \\
0.38\end{array}$ & $\begin{array}{l}\text { Sundays: } \\
\text { Nitrate } \\
\text { Nitrite }\end{array}$ & $\begin{array}{c}0.64 \\
-0.25\end{array}$ & $\begin{array}{l}-0.77 \\
-0.97\end{array}$ & & $\begin{array}{l}0.41 \\
0.06\end{array}$ \\
\hline \begin{tabular}{|l|} 
Gamtoos: \\
0 \\
1 \\
2
\end{tabular} & $\begin{array}{l}0.99 \\
0.24 \\
0.06\end{array}$ & $\begin{array}{c}80.4 \\
1.0 \\
0.1\end{array}$ & $\begin{array}{c}<0.001 \\
0.98 \\
0.97\end{array}$ & $\begin{array}{l}\text { Gamtoos: } \\
\text { Nitrite } \\
\text { Phosphate } \\
\text { Ammonia } \\
\text { Nitrate }\end{array}$ & $\begin{array}{l}-0.28 \\
-0.10 \\
-0.24 \\
-0.14\end{array}$ & $\begin{array}{c}-0.65 \\
-0.04 \\
0.31 \\
-0.15\end{array}$ & $\begin{array}{l}0.20 \\
0.40 \\
0.09 \\
0.37\end{array}$ & $\begin{array}{l}0.08 \\
0.01 \\
0.06 \\
0.02\end{array}$ \\
\hline
\end{tabular}

estuarine system. Higher concentrations of nitrite and ammonia were measured in the Kromme and Swartkops Rivers, while the mean concentrations of these nutrients in the Sundays and Gamtoos Estuaries were lower in the inflowing freshwater compared to the upper estuarine reaches (Table 1) (a detailed description of means and variability of nutrient concentrations is given in Scharler and Baird 2003a; b).

Discriminant analysis was first performed for all 4 estuaries to detect differences in terms of the inorganic dissolved nutrients (phosphate, nitrate, nitrite, ammonia) between the lower, middle and upper estuarine reaches and the river for each of the estuaries separately. Since the Gamtoos and Sundays Estuaries were, in general, stratified in terms of salinity and nutrients, while the Swartkops and Kromme Estuaries were well mixed, the nutrient data were depth-averaged to compensate for this difference and to reduce the possible misclassification of cases in the discriminant analysis. Since the data were sampled over different time periods and in variable frequencies, it was assumed that the pooled data (temporally and geographically) are representative of the nutrient status of the various regions of the estuaries.

The summary of the stepwise analysis in Table 2 shows that there was no statistically significant difference in terms of all 4 inorganic dissolved nutrients between the reaches of the Kromme Estuary. Phosphate was the only discriminating factor in the case of the Swartkops Estuary, due to the steep decrease in concentration from the river to the estuarine mouth. Nitrate and nitrite were identified as discriminating factors for the Sundays Estuary, and only the first discriminant function is statistically significant, separating the Sundays River from the estuarine reaches. For the Gamtoos Estuary all 4 inorganic dissolved nutrients were included in the model as discriminating factors, and nitrite had the strongest discriminating power. Only the first discriminant function, separating the river from the estuarine reaches, was statistically significant (Table 2). Discriminant analysis was then performed to assess differences between the 4 estuaries (Table 3, Fig. 2). The lower, middle and upper estuarine reaches as well as the river sampled just above the tidal head were compared between the 4 estuaries. The lower reaches of all 4 estuaries showed no difference in their dissolved inorganic nutrient concentrations. In the middle reaches phosphate was the best discriminating factor, followed by ammonia and nitrate. The differences in the upper reaches between the 4 estuaries are more pronounced, and phosphate was again identified as the parameter with the highest discriminating power. The classification of data was best for the Swartkops Estuary $(100 \%)$ and lowest for the Sundays Estuary (42.9\%). Two discriminant functions were statistically significant, where the first separates the Swartkops and the second the Gamtoos Estuary from the remaining estuaries. Lastly, in the riverine reaches, all 4 inorganic dissolved nutrients were included as discriminating factors and phosphate had again the best discriminating power followed by nitrate, nitrite and ammonia. The classification was best for the Sundays Estuary (100\%) and lowest for the Gamtoos Estuary (50\%). Two statistically significant discriminant func- 


\section{TABLE 3}

Results of discriminant analysis of the various reaches between the 4 estuaries. Summary of stepwise analyses: list of variables with discriminant power; Discriminant functions: give results of canonical analyses and significance of the canonical roots that add to the discrimination between groups; Classification matrix: presents to which group (here: lower, middle, upper, riverine reaches) a case (here: concentrations of nutrients included in the analysis) most likely belongs; Discriminant loadings: measure the simple linear correlation between the variables and the discriminant function; Potency Index: A composite measure of the discriminatory power of a predictor variable. Only the variables which discriminate statistically significant between the estuaries are listed. There was no difference between the lower reaches of the 4 estuaries.

\begin{tabular}{|c|c|c|c|c|c|c|c|c|}
\hline \multicolumn{4}{|c|}{ Summary of stepwise analysis: } & \multicolumn{5}{|c|}{ Classification Matrix:\% correctly classified: } \\
\hline & $F$ to enter & p-level & & & Middle & \multicolumn{2}{|c|}{ Upper } & River \\
\hline Middle Reaches: & & & & Kromme & 81.8 & \multicolumn{2}{|c|}{80.0} & 60.0 \\
\hline Phosphate & 12.5 & $<0.001$ & & Swartkops & 85.7 & \multicolumn{2}{|c|}{100.0} & 85.7 \\
\hline Ammonia & 2.6 & 0.07 & & Sundays & 42.9 & \multicolumn{2}{|c|}{42.9} & 100.0 \\
\hline Nitrate & 1.5 & 0.25 & & Gamtoos & 50.0 & \multicolumn{2}{|c|}{83.3} & 50.0 \\
\hline \multirow{4}{*}{$\begin{array}{l}\text { Upper Reaches: } \\
\text { Phosphate } \\
\text { Nitrite } \\
\text { Nitrate }\end{array}$} & \multirow{4}{*}{$\begin{array}{c}24.1 \\
6.2\end{array}$} & \multirow{4}{*}{$\begin{array}{c}<0.001 \\
0.003 \\
0.10\end{array}$} & & Total & 67.7 & & & 78.3 \\
\hline & & & & \multicolumn{5}{|c|}{ Proportional chance criterion: } \\
\hline & & & & & \multirow[t]{7}{*}{27.2} & \multirow{7}{*}{\multicolumn{2}{|c|}{25.5}} & \multirow[t]{7}{*}{24.5} \\
\hline & & & & & & & & \\
\hline River: & & & & & & & & \\
\hline Phosphate & 11.6 & $<0.001$ & & & & & & \\
\hline Nitrate & 3.9 & 0.03 & & & & & & \\
\hline Nitrite & 2.4 & 0.10 & & & & & & \\
\hline Ammonia & 1.7 & 0.20 & & & & & & \\
\hline \multicolumn{4}{|c|}{ Discriminant functions: Statistical Significance: } & \multicolumn{5}{|c|}{ Discriminant loadings: } \\
\hline $\begin{array}{l}\text { Discriminant } \\
\text { function } \\
\text { removed }\end{array}$ & $\begin{array}{l}\text { Canoni- } \\
\text { cal } \mathbf{R}\end{array}$ & $\begin{array}{l}\text { Chi- } \\
\text { square }\end{array}$ & p-level & & $1^{\text {st }}$ & $2^{\text {nd }}$ & $3^{\text {rd }}$ & $\begin{array}{l}\text { Po- } \\
\text { tency } \\
\text { Index }\end{array}$ \\
\hline $\begin{array}{l}\text { Middle Reaches: } \\
0\end{array}$ & 0.8 & 34.3 & $<0.001$ & $\begin{array}{l}\text { Middle reaches: } \\
\text { Phosphate }\end{array}$ & -0.89 & 0.16 & 0.43 & 0.79 \\
\hline 1 & 0.4 & 7.7 & 0.10 & Ammonia & 0.07 & 0.45 & 0.89 & 0.01 \\
\hline 2 & 0.3 & 3.2 & 0.07 & Nitrate & 0.13 & 0.96 & 0.23 & 0.02 \\
\hline $\begin{array}{l}\text { Upper Reaches: } \\
0\end{array}$ & 0.9 & 54.6 & $<0.001$ & $\begin{array}{l}\text { Upper Reaches: } \\
\text { Phosphate }\end{array}$ & -0.86 & -0.50 & -0.09 & 1.00 \\
\hline 1 & 0.7 & 16.4 & 0.003 & Nitrite & 0.37 & -0.75 & 0.55 & 0.70 \\
\hline 2 & 0.3 & 1.7 & 0.19 & Nitrate & 0.25 & -0.65 & -0.72 & 0.49 \\
\hline $\begin{array}{l}\text { River: } \\
0\end{array}$ & 0.9 & 39.1 & $<0.001$ & $\begin{array}{l}\text { River: } \\
\text { Phosphate }\end{array}$ & 0.74 & 0.53 & 0.40 & 0.83 \\
\hline 1 & 0.7 & 15.0 & 0.02 & Nitrate & -0.41 & 0.38 & 0.65 & 0.31 \\
\hline 2 & 0.5 & 4.1 & 0.13 & Nitrite & -0.13 & -0.48 & 0.84 & 0.25 \\
\hline & & & & Ammonia & 0.08 & -0.30 & -0.09 & 0.10 \\
\hline
\end{tabular}

tions separate the Swartkops (first function) and the Kromme (second function) Estuary from the remaining estuaries.

The canonical scores are plotted in Fig. 2 for the first discriminant functions (or canonical roots), and shows how each discriminant function contributes to the discrimination between groups. The differences between the estuaries become more pronounced from the middle to the riverine reaches (there was no statistically significant difference between the lower reaches of the 4 estuaries), and the Swartkops is most separated from the other estuaries. In the riverine reaches, the Gamtoos and Sundays Estuaries had similar canonical scores derived from the nutrient concentrations, whereas the Swartkops and Kromme Estuaries differed from the former 2 and from each other. The classification accuracy of the data into the various groups was always fairly high and always above the proportional chance criterion (Tables 1,2), which describes the probability of right classification into a group by chance only (Hair et al., 1992). The only exception was a low hit ratio of $14.3 \%$ of the middle reaches of the Sundays Estuary as a result of a comparison of the Sundays estuarine reaches (Table 2).

\section{Discussion}

Although the differences within the estuaries are either absent (Kromme Estuary) or pronounced only for some (Swartkops: phosphate, Gamtoos and Sundays: nitrate and nitrite) but not all nutrients, it was obvious that the differences between the estuaries was the least pronounced in the lower reaches, and most pronounced in the upper and riverine reaches. This clearly describes the filtering capacity, largely ascribed to the metabolic activity of organisms in the water column and sediment of these estuaries for land-derived nutrients and its importance as a natural purification system. Concentrations of dissolved inorganic phosphate (DIP)in the coastal waters along the south-east Cape coast varies between 0.02 and $0.3 \mu \mathrm{M}$, whereas concentrations of between $0.4 \mu \mathrm{M}$ and $0.8 \mu \mathrm{M}$ were measured in the lower reaches of the estuaries. Dissolved inorganic nitrogen (DIN) in coastal water range between 0.4 and $0.8 \mu \mathrm{M}$ (Switzer and Waldron, 2001; Baird, 2001), whilst a mean of $7.25 \mu \mathrm{M}(\mathrm{SD}=6.4$, $\mathrm{n}=12$ ) was measured during spring low tide in the lower reaches of the estuaries (Scharler and Baird, 2003a; b). Concentrations 
are thus generally lower in the coastal seas than in the estuaries. However, the dilution effect of seawater was most probably limited because of the fact that samples were taken at spring low ebb tides. Winter and Baird (1991) calculated a net export of orthophosphate from the Swartkops Estuary, which was in accordance with many other studies testing the 'outwelling' hypothesis of estuaries (Odum 1980). The net export of other dissolved inorganic nutrients such as ammonium, nitrite, nitrate, and dissolved inorganic carbon (DIC) have also been reported by Baird and Winter (1990) for the Swartkops Estuary. The low DIP and DIN concentrations in the coastal waters must have some dilution effect during tidal floods of nutrients in the lower reaches of this estuary, and excess material are most probably exported on the ebb tide as suggested by Baird et al (1987), Baird and Winter (1990), and Winter and Baird (1991). Similar quantitative results are unfortunately not available for any of the other estuaries discussed in this paper. However, the decline in the nutrient concentrations along the axis of the estuaries is significant, and estuaries in this case perform a similar function as wetlands and marshes. The entrapment of land-derived nutrients is an important factor in the high productivity of estuaries, which around the world sustain millions of people through their productivity (e.g. fisheries). Gabric and Bell (1993) state that $\mathrm{N}$ and P loadings increased over the past few decades by $42.5 \%$ and $11.4 \%$ respectively in developed countries and by $221 \%(\mathrm{~N})$ and $161 \%(\mathrm{P})$ in developing countries, where the absolute fertiliser application rate is as yet not as high as in developed countries. A review of nitrogen fluxes from continents surrounding the North Atlantic reported that riverine nitrogen inputs to the North Atlantic have increased eleven-fold in the North Sea region, six-fold for all of Europe and three-fold for the North American continent (Howarth, 1998). In a thorough review of inorganic nutrient loading to the coastal seas, Smith et al. (2003) estimated that the total global loads of dissolved inorganic phosphate and dissolve inorganic nitrogen are almost three times the amount calculated by Meybeck (1982) for the year 1970. Fertilisers applied to agricultural fields are in general not entirely used, so that a substantial amount is washed from the soil into rivers and estuaries which puts increasing demands on the filtering role of these ecosystems. An over-supply of nutrients is documented extensively in the literature through eutrophication of estuaries and the continental shelf (e.g. Conley et al., 1993; Paerl, 1997; Howarth, 1998). The occurrence of hypoxia appears to be a common phenomenon during late summer in many estuaries along the eastern seaboard of the continental United States (Baird et al., 2004). Eutrophication is also associated with changes in the food web structure, e.g. increased phytoplankton biomass at the expense of macrophytes, or the shift from edible to inedible phytoplankton species and the consequences for higher trophic levels (e.g. Nixon, 1993; Roelke et al., 1999, Baird et al., 2004).

The overall nutrient loads reaching South African estuaries is still only a small fraction compared to those of Europe and North America. In Australia, where estuaries experience similar flood-drought cycles as in South Africa (Eyre, 1998), eutrophication is a threat to some estuarine systems (e.g. Summers et al., 1999), but others are reported to carry relatively low nutrient concentrations (Eyre, 1997; Eyre and Balls, 1999). On those continents where the filtering capacity of estuaries has been exceeded by far, restoration efforts are an important feature in estuarine research and management, in order to decrease the nutrient supply to rivers, estuaries and the conti- nental shelf (e.g. Gabric and Bell, 1993; Nixon, 1993; Bricker and Stevenson, 1996; Rendell et al., 1997; Smit et al., 1997; Attrill, 1998; Summers et al., 1999).

Freshwater reduction is still perceived as a bigger threat to coastal areas in South Africa than eutrophication. A decreased freshwater supply to estuaries in agricultural areas can result in a decreased flushing potential of freshets and floods. Since agriculture is most likely to be a growing industry in the future instead of decreasing or stagnating, the pollution pressure on South African estuaries will increase. Because of the decrease in the flushing of estuaries, in terms of the magnitude and frequency of floods, the water residence times in the estuaries will increase and therefore also enhance the potential for eutrophication. In the Gamtoos Estuary, where phytoplankton blooms do exist (Snow et al., 2000), frequent flushing of the estuary is believed to clear the system from accumulated fertilisers and so prevented large scale eutrophication to date (Scharler and Baird, 2003b). A similar situation might be true for the Sundays Estuary, where algal blooms are well documented (Hilmer and Bate, 1990).

In conclusion, results from this study show that the variability in nutrient concentrations is greater in the upper reaches than in the lower reaches of the 4 systems investigated. The fact that the different estuaries were not sampled over the same time period, or that the frequency of samples and sampling varied between systems, could have resulted in greater variability than if sampling would have taken place simultaneously in the estuaries. However, the close proximity of the estuaries, and the relative homogeneous climate in which they occur, justifies the comparison of the results, which is reflected in the similar trends observed in the distribution of nutrient concentrations.

The absorptive or filtering capacity of the estuaries is a function of the inherent metabolic activities within an estuary leading to reduced nutrient concentrations in the lower reaches of the estuary. Reduced nutrients in the lower reaches may affect the system's productivity and diversity, which can ultimately be traced back to reduced freshwater inflow and the associated decreased levels of nutrient inputs. The cause and effect of river flow and water quality on the one hand, and the filtering capacity of estuaries on the other, imply a delicate balance between them that has management implications. However, the complex interactions between river flow, tidal pulsing, and intertidal wetlands in the control of nutrient levels in estuaries are not yet fully understood (Allanson et al., 2000).

\section{Acknowledgements}

We thank the National Research Foundation, South Africa, and the Water Research Commission, South Africa, for funding, and the Department of Botany and Biochemistry at the University of Port Elizabeth for use of their laboratories and equipment. Thanks also go to all people for their valuable and much appreciated help in the field.

\section{References}

ALLANSON BR, MAREE B and GRANGE N (2000) An introduction to the chemistry of the water column of the Knysna estuary with particular reference to nutrients and suspended solids. Trans. Roy. Soc. S. Afr. 55 (2) 141-162.

ARCHIBALD REM (1983) The Diatoms of the Sundays and Great Fish Rivers in the Eastern Cape Province of South Africa. AR Gantner 
Verlag Kommanditgesellschaft, Vaduz. 431 pp.

ATTRILL MJ (1998) A Rehabilitated Estuarine Ecosystem. The Environment and Ecology of the Thames Estuary. Kluwer Academic Publishers, Dordrecht. 260 pp.

BAIRD D, WINTER PED and WENDT G (1987) The flux of particulate material through a well-mixed estuary. Continental Shelf. Res. 7 1399-1403.

BAIRD D (2001) Estuaries of South Africa: Kromme River Estuary, Gamtoos River Estuary, Swartkops River Estuary, Sundays River Estuary. In: Dupra V, Smith SV, Marshall-Crossland JI and Crossland CJ (eds.) Estuarine Systems of Sub-Saharan Africa: Carbon, Nitrogen and Phosphorus Fluxes. . LOICZ Reports \& Studies No 18 39-59.

BAIRD D and WINTER D (1990) Annual flux budget of dissolved inorganic nutrients through a well-mixed estuary. In: Michaelis W (ed.) Estuarine Water Quality Management: Monitoring, Modelling and Research. Coastal and Estuarine Studies 36 335-340.

BAIRD D, CHRISTIAN RR, PETERSON CH and JOHNSON GA (2004) Consequences of hypoxia on estuarine ecosystem function: energy diversion from consumers to microbes. J. Ecol. Appl. 14 (3) 805-822.

BATE GC and HEELAS BV (1975) Studies on the nitrate nutrition of two indigenous Rhodesian grasses. J. Appl. Ecol. 12 941-952.

BRICKER SB and STEVENSON JC (1996) Nutrients in coastal waters: a chronology and synopsis of research. Estuaries 19 (2B) 337-341.

CONLEY DJ, SCHELSKE CL and STOERMER EF (1993) Modification of the biogeochemical cycle of silica with eutrophication. Mar. Ecol. Progr. Ser. 101 179-192.

EYRE B and BALLS P (1999) A comparative study of nutrient behavior along the salinity gradient of tropical and temperate estuaries. Estuaries 22 313-326.

EYRE B (1997) Water quality changes in an episodically flushed subtropical Australian estuary: A 50 year perspective. Mar. Chem. 59 177-187.

EYRE B (1998) Transport, retention and transformation of material in Australian estuaries. Estuaries 21 (4A) 540-551.

GABRIC AJ and Bell RF (1993) Review of the Effects of Non-point Nutrient Loading on Coastal Ecosystems. Austr. J. Mar. Freshwater Res. 44 261-283.

GORDON DC, BOUDREAU PR, MANN KH, ONG J-E, SILVERT WL, SMITH SV, WATTTAYKOM F, WULFF F and YANAGI T (1996) LOICZ Biogeochemical Modelling Guidelines. LOICZ/ R\&S/95, vi+P6. LOICZ, Texel, The Netherlands.

HAIR, JF, ANDERSON RE, TATHAM RL and BLACK WC (1992) Multivariate Analysis with Readings. New York: Macmillan Publisher.

HEYDORN AEF and GRINDLEY JR (1981) Estuaries of the Cape. Part 2. Synopsis of Available Information on Individual Systems. CSIR Stellenbosch: National Research Institute for Oceanology.

HILMER T and BATE GC (1990) Covariance analysis of chlorophyll distribution in the Sundays River estuary, Eastern Cape. S. Afr. J. Aquat. Sci. 16 37-59.

HOWARTH RW (1998) An assessment of human influences on fluxes of nitrogen from the terrestrial landscape to the estuaries and continental shelves of the North Atlantic Ocean. Nutr. Cycl. Agroecosys. 52 213-223.

MACKAY HM and SCHUMANN EH (1990) Mixing and circulation in the Sundays River estuary, South Africa. Estuar. Coast. Shelf Sci. 31 203-216.

MACKAY HM (1993) The Impact of Urban Runoff on the Water Quality of the Swartkops Estuary: Implications for Water Quality Management. Talbot \& Talbot. Industrial and Environmental Management c.c.

MEYBECK M (1982) Carbon, nitrogen, and phosphorus transport by world rivers. Am. J Sci. 282 401-450.

MIDGLEY DC, PITMAN WV and MIDDLETON BJ (1994) Surface Water Resources of South Africa 1990. Water Research Commission Report No 298/1/94.

MORANT P and QUINN N (1999) Influence of man and management of South African estuaries. In: Allanson BR and Baird D (eds.) Estuaries of South Africa. Cambridge University Press, Cambridge. 289-320.
NIXON SW (1993) Nutrients and Coastal Waters. Too much of a good thing? Oceanus 36 (1) 38-47.

NOBLE RJ and HEMENS J (1978) Inland Water Ecosystems in South Africa: A Review of Research Needs. CSIR Pretoria, South Africa.

ODUM EP (1980) The status of three ecosystem-level hypotheses regarding salt marsh estuaries: Tidal subsidy, outwelling and detritus-based food chains. In: Kennedy V (ed.) Estuarine Perspectives. Academic press, New York. 485-495.

PAERL HW (1997) Coastal eutrophication and harmful algal blooms: Importance of atmospheric deposition and groundwater as 'new' nitrogen and other nutrient sources. Limnol. Oceanogr. 42 (5/2) $1154-1165$.

REDDERING JSV and ESTERHUYSEN K (1981a) Sedimentation in the Swartkops Estuary. Rosie Report No 1, Department of Geology, University of Port Elizabeth, Port Elizabeth.

REDDERING JSV and ESTERHUYSEN K (1981b) Sedimentation in the Sundays Estuary. Rosie Report No. 3, Department of Geology, University of Port Elizabeth, Port Elizabeth.

REDDERING JSV and ESTERHUYSEN K (1983) Sedimentation in the Kromme Estuary. Rosie Report No. 6, Department of Geology, University of Port Elizabeth, Port Elizabeth.

REDDERING JSV and RUST IC (1990) Historical changes and sedimentary characteristics of southern African estuaries. S. Afr. J. Sci. 86 425-428.

RENDELL AR, HORROBIN TM, JICKELLS TD, EDMUNDS HM, BROWN J and MALCOLM SJ (1997) Nutrient cycling in the Great Ouse Estuary and its impact on nutrient fluxes to The Wash, England. Estuar. Coast. Shelf Sci. 45 653-668.

ROELKE DL, ELDRIDGE PM and CIFUENTES LA (1999) A model of phytoplankton competition for limiting and nonlimiting nutrients: Implication for development of estuarine and nearshore management schemes. Estuaries 22 (1) 92-104.

SCHARLER UM and BAIRD D (2000) The effects of an experimental freshwater release from the Mpofu dam on the Kromme estuary. 1 . General description of the study area and physico-chemical responses. Water $S A 26$ 291-300.

SCHARLER UM and BAIRD D (2003a) The influence of catchment management on salinity, nutrient stochiometry and phytoplankton biomass of Eastern Cape estuaries, South Africa. Estuar. Coast. Shelf Sci. 56 (3/4) 735-748.

SCHARLER UM and BAIRD D (2003b) The nutrient status of the agriculturally impacted Gamtoos Estuary, South Africa, with special reference to the river-estuarine interface region (REI). Aquatic Conserv: Mar. Freshw. Ecosyst. 13 99-119.

SCHARLER UM, BAIRD D, ASTILL H and ADAMS J (2003) Water column, interstial and boundary layer nutrient staus in and around the river-estuary interface (REI) zone of the Gamtoos Estuary. In: Whitfield AK and Wood AD (eds.) Studies on the River-Estuary Interface Region of Selected Eastern Cape Estuaries. Water Research Commission Report No 756/1/03 6-121.

SCHUMANN EH and PEARCE MW (1997) Freshwater inflow an estuarine variability in the Gamtoos estuary: Implications for watershed management. Estuaries 19(2B) 124-133.

SMIT H, VAN DER VELDE G, SMITS R and COOPS H (1997) Ecosystem responses in the Rhine-Meuse Delta during two decades after enclosure and steps toward estuary restoration. Estuaries $\mathbf{2 0}$ (3) 504-520.

SMITH SV, SWANEY DP, TALAUE-McMANUS L, BARTLEY, JD, SANDHEI PT, McLAUGHLIN, CJ, DUPRA, VC, CROSSLAND CJ, BUDDEHEIMER, RW, MAXWELL BA and WULFF F (2003) Humans, hydrology, and the distribution of organic nutrient loading to the ocean. BioSci. 53 (3) 235-245

SNOW GC, ADAMS JB and BATE GC (2000) Effect of river flow on estuarine microalgal biomass and distribution. Estuar. Coast. Shelf Sci. 51 (2) 255-266.

SNOW GC, BATE GC, ASTILL H and ADAMS JB (2003) Structure and dynamics of estuarine microalgae in the Gamtoos Estuary in relation to the river-estuary interface (REI) region. In: Whitfield AK and Wood AD (eds.) Studies on the River-Estuary Interface Region of Selected Eastern Cape Estuaries. WRC Report No 756/1/03 122-181. 
SOLÓRZANO L (1969) Determination of ammonia in natural waters by the phenolhypochlorite method. Limnol. Oceanogr. 14 799-801.

STRICKLAND JD and PARSONS TR (1972) A practical handbook of seawater analysis. Bull. Fish. Res. Board of Canada 167311 pp.

SUMMERS RN, VAN GOOL D, GUISE NR, HEADY GJ and ALLEN $T$ (1999) The phosphorus content in the run-off from the coastal catchment of the Peel Inlet and Harvey Estuary and its association with land characteristics. Agr. Ecosyst. Environ. 3 271-279.

SWITZER T and WALDRON H (2001) Estuaries of South Africa: Knysna Lagoon. In: Dupra V, Smith SV, Marshall-Crossland JI and
Crossland CJ (eds.) Estuarine Systems of Sub-Saharan Africa: Carbon, Nitrogen and Phosphorus Fluxes. LOICZ Reports \& Studies No 18 37-43.

WHITFIELD AK (2000) Available Scientific Information on Individual South African Estuarine Systems. Water Research Commission Report No. 557/3/00 1-217 pp.

WINTER PED and BAIRD D (1991) The exchange of phosphate between the Swartkops Estuary and Algoa Bay. S. Afr. J. Sci. 87 192-197. 